\title{
ANALISIS PERKEMBANGAN KAWASAN TERBANGUN BAGIAN UTARA KOTA PAYAKUMBUH
}

\author{
Alil Muhakym \\ Program Studi Geografi \\ Fakultas Ilmu Sosial Universitas Negeri Padang \\ Email :alilmuhakym97@gmail.com
}

\begin{abstract}
ABSTRAK
Penelitian ini bertujuan untuk mengetahui perubahan penggunaan lahan dan luas perubahan penggunaa n lahan kawasan terbangun Bagian Utara Kota Payakumbuh pada tahun 2007 dan. Jenis penelitian ini adalah deskriptif kuantitatif. Data yang digunakan adalah Citra Quickbird tahun 2007 dan tahun 2016. Hasil penelitian ini menunjukkan untuk: (1) perubahan penggunaan lahan untuk kawasan terbangun Bagian Utara Kota Payakumbuh ini selalu meningkat dari tahun ke tahun yaitu terdapat kenaikan jumlah luas perubahan, (2) Perubahan luas lahan terbangun bagian utara Kota Payakumbuh selama kurun waktu 10 tahun terjadi peningkatan sebesar 266 ha dimana pada tahun 2007 yaitu sebesar 150ha meningkat menjadi 416ha pada tahun 2016.
\end{abstract}

Kata Kunci :perubahan penggunaan lahan, luas perubahan penggunaan lahan

\begin{abstract}
This study aims to determine changes in land use and extensive changes in land use area built in northern Payakumbuh City in 2007 da. This type of research is descriptive quantitative. The data used are Quickbird Image in 2007 and 2016. The results of this study indicate to: (1) The change of land use for the area built up northern Payakumbuh City is always increasing from year to year that there is an increase in the number of changes. (2) Changes in land area built up north Payakumbuh during the period of 10 years an increase of 266 ha where in 2007 that is 150ha increased to 416 ha in 2016
\end{abstract}

Keywords: land use change, area of land use change

\begin{tabular}{l}
\hline${ }^{1}$ Mahasiswa Jurusan Geografi FIS UNP \\
${ }^{2}$ Dosen Jurusan Geografi FIS UNP Ahyuni, ST, M.Si ${ }^{1}$ dan Febriandi, S.Pd, M.Si ${ }^{2}$
\end{tabular} 


\section{PENDAHULUAN}

Perubahan penggunaan lahan yang terjadi umumnya disebabkan karena adanya peningkatan jumlah penduduk disebuah wilayah. Hal ini menyatakan bahwa setiap tahun tanpa disadari laju pertumbuhan penduduk tidak pernah berhenti dan senantiasa menunjukkan peningkatan diikuti oleh adanya penambahan lahan pemukiman. Sebagai contoh kasus dapat dilihat pada wilayah Sumatera Barat yang mengalami peningkatan jumlah penduduk diikuti dengan perubahan penggunaan lahan yang cukup pesat.

Seiringberkembangnyazaman, Peningkatan jumlah penduduk ini seiring dengan peningkatan kebutuhan akan lahan untuk tempat tinggal. Setiap tahunnya terjadi pengurangan luas lahan pertanian di Kota Payakumbuh bagian utara akibat pembangunan permukiman.

Kawasan bagian utara Kota Payakumbuh terjadinya peningkatan pembangunan yang cukup pesat seperti pembangunan, pemukiman, sarana dan prasarana, pertanian, industri dan jasa. Namun, kegiatan pembangunan ini mendesak areal pertanian yang ada di wilayah ini.

Pengurangan areal pertanian ini tidak hanya disebabkan oleh kebutuhan dan tuntutan wilayah untuk membangun wilayahnya tetapi juga disebabkan karena terjadinya peningkatan jumlah penduduk di bagian utara Kota Payakumbuh.

Adapun jumlah penduduk bagian utara Kota Payakumbuh pada tahun 2006 adalah 27.311 jiwa. Sedangkan pada tahun 2016 jumlah penduduk bagian utara Kota Payakumbuh adalah sebanyak 30.679 jiwa.
Tanah merupakan salah satu sumber daya alam yang memiliki banyak fungsi penting dalam ekosistem diantaranya adalah sebagai pertumbuhan tanaman habitat bagi jasad tanah media bagi kontruksi sistem daur ulang bagi unsur hara dan sisa-sisa organik serta sistem bagi pasokan dan penyaringan/penjernihanair.

Permasalahan dalam penggunaan lahan sifatnya umum di seluruh dunia, baik di negara maju maupun negara berkembang, terutama akan menjadi menonjol bersamaan dengan terjadinya peningkatan jumlah penduduk Sehingga dengan adanya peningkatan kebutuhan akan lahan mengakibatkan perubahan penggunaan lahan pada kawasan bagian utara Kota Payakumbuh.

1. Lahan

Lahanmerupakanlingkunganfisik yang terdiridariiklim, relief, tanah, air, danvegetasiserta benda yang ada di atasnya sepanjangadapengaruhnyaterhadappengguna anlahan.Termasuk di dalamnyajugakegiatanmanusia di masalaludansekarangsepertihasilreklamasila ut, membersihkanvegetasidanjugahasil yang merugikansepertitanah yang tersalinitasi (Muta'ali, 2012).

Lahan tersebut mempunyai ciri-ciri antara lain merangkum semua tanda pengenal seperti biosfer, atmosfer, tanah, geologi, timbulun, atau relief, hidrologi, populasi, tumbuhan dan hewan serta hasil kegiatan manusia masa lalu dan masa kini yang bersifat mantap dan mendaur. 
2. Perubahan penggunaan lahan untuk permukiman

Penggunaanlahanmerupakansetiapbentu kintervensimanusiaterhadaplahandalamrang kamemenuhikebutuhanhidupnyatermasukke adaanalamiah yang belumterpengaruholehkegiatanmanusia (RustiadidanWafda, 2007)

Penggunaan lahan berhubungan dengan kegiatan manusia pada sebidang lahan sedangkan penutup lahan adalah perwujudan fisik obyek - obyek yang menutupi lahan tanpa mempersoalkan kegiatan manusia terhadap obyek-obyek tersebut. Satuansatuan tutupan lahan kadang-kadang juga memiliki sifat tutupan lahan alami (Lillesand/Kiefer, 1994).

Penggunaan lahan adalah setiap bentuk campur tangan (intervensi) manusia terhadap lahan dalam rangka memenuhi kebutuhan hidupnyabaik material maupun spiritual Penggunaan lahan dapat dikelompokkan ke dalam dua kelompok besar yaitu (1) penggunaan lahan pertanian (2) penggunaan lahan non pertanian. Penggunaan lahan non pertanian terdiri dari permukiman, sarana dan prasarana, industri, perdagangan dan jasa. Penggunaan lahan secara umum tergantung pada kemampuan lahan dan pada lokasi lahan.

Seiring dengan bertambahnya penduduk maupun adanya kebijakan dari pemerintah daerah, penggunaan lahan dapat mengalami perubahan.Karakteristikpenutupan/pengguna anlahansuatuwilayahsangatdipengaruhioleh kondisi biofisikmaupun sosial ekonomimasyarakatnya (Haryadi, 2007).
3. GIS Untuk Analisa Perubahan Penggunaan Lahan untuk Kawasan Permukiman

Penggunaan Arcgis 10.1 sangat tepat untuk melihat segala bentuk perubahan yang terjadi di permukaan bumi, termasuk untuk mengetahui perubahan penggunaan lahan untuk kawasan terbangun di suatu wilayah. Selain data dan informasi yang akan diperoleh tersebut lebih rinci, proses dalam mengadakan pengamatan maupun perolehan informasi perubahan perubahan lahan yang dilihat dari aspek luas dan polanya menjadi lebih cepat karena perangkat ini mampu bekerja dalam waktu yang singkat sehingga tidak memerlukan waktu dan tenaga yang banyak.

Penggunaan Arcgis 10.1 sangat tepat untuk melihat segala bentuk perubahan yang terjadi di permukaan bumi

4. Interpretasi Citra

Analisis, pemrosesan, daninterpretasi data dilakukandenganbantuan computer jika data PJ tersediadalam format digital. Pengelolaancitrasecara digital dapatdigunakanuntukmeningkatkankenampa kancitra.Analisissecara digital jugamemungkinkankitasecaraotomatismengi dentifikasi target danmenyeleksiinformasitanpaintrevensiman usiasecara manual (Indarto, 2014).

Dari permasalahan di atas, makapenelititertarikuntukmelakukanpeneliti an yang mengkajitentang "Analisis Perkembangan Kawasan Terbangun Bagian Utara Kota Payakumbuh."

Tujuandaripenelitianiniadalahmengeta huiperubahan penggunaan lahan pada kawasan terbangun bagian utara Kota Payakumbuh dan mengetahui luas perubahan 
penggunaan lahan pada kawasan terbangun bagian utara Kota Payakumbuh.

\section{METODE PENELITIAN}

PenelitianinidilakukanpadabulanJulis ampai Desember 2017 yang berlokasi di Kawasan Bagian Utara Kota Payakumbuh.

Gambar 1 merupakan Peta Lokasi penelitian yang terletak di Bagian Utara Kota Payakumbuh

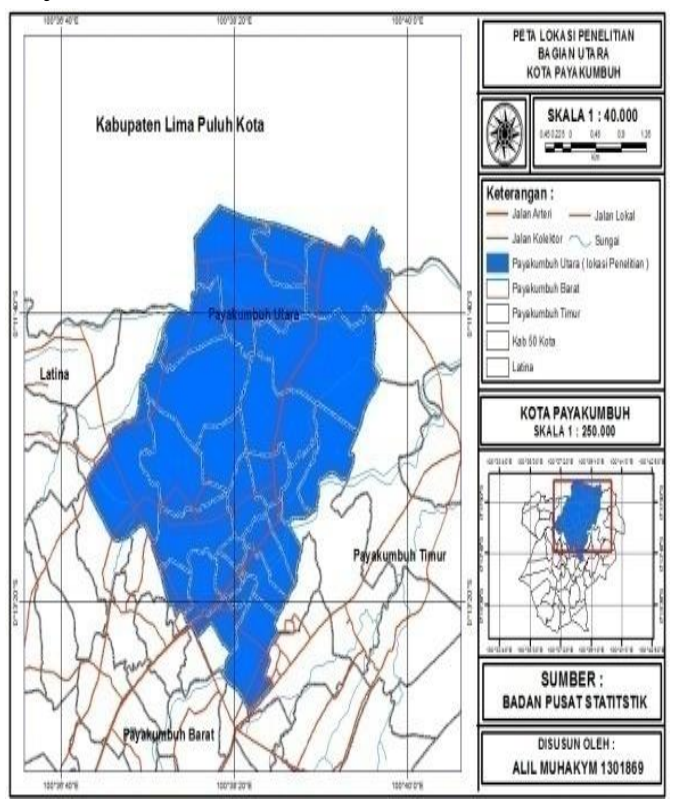

Gambar 1. PetaLokasiPenelitian

Jenispenelitianiniadalahpenelitiandeskr iptifkuantitatif. Jenis penelitian ini adalah kuantitatif dengan menggunakan metode deskriptif.

Menurut Nawi dan Khairani (2009:25) bahwa penelitian deskriptif adalah penelitian yang bermaksud untuk menggambarkan gejala/keadaan tentang suatu variabel apa adanya di lapangan dan melihatperubahan dan luas penggunaan lahan untuk kawasan terbangun bagian utara kota Payakumbuh..

Alat

yang digunakandalampenelitianadalah laptop yang dilengkapisoftware ArcGIS 10.1, GPS, Kamera, danalattulis.Bahan yang digunakanadalahPeta penggunaan lahan tahun 2007 dan 2016 dan Citra Quickbird tahun 2007 dan 2016.

Melakukan intrepetasi peta penggunaan lahan Kota Payakumbuh bagian utara tahun 2007 dengan alat analisis Arcgis 10.1

Melakukan intrepetasi peta penggunaan lahan Kota Payakumbuh tahun 2016 dengan alat ArcGis 10.

Teknik analisis data yang digunakan untuk mengetahui perubahan penggunaan lahan untuk kawasan permukiman bagian utara Kota Payakumbuh dilakukan dengan:

1. Interpretasi peta terhadap 2 peta penggunaan lahan Kota Payakumbuh tahun 2007 dan peta penggunaan lahan Kota Payakumbuh tahun 2016 dengan Arcgis 10.1.

2. Overlay peta penggunaan lahan Kota Payakumbuh Bagian utara tahun 2007 dan 2016 dengan peta administrasi dan peta permukiman kota Payakumbuh menggunakan alat analisis Arcgis 10.1.

3. Untuk mengetahui luas perubahan penggunaan lahan untuk kawasanpermukiman dilakukan denganmenghitung perubahan luas lahan untuk permukiman dengan Arcgis 10.1

4. Untuk mengetahui perubahan penggunaan lahan dilakukan dengan cara analisis peta penggunaan lahan.

\section{HASIL DAN PEMBAHASAN \\ Deskripsi Wilayah}

Kawasan bagian utara sama halnya dengan Kecamatan Payakumbuh Utara. Kecamatan Payakumbuh Utara adalah kecamatan yang terletak disebelah utara wilayah Kota Payakumbuh dan merupakan gerbang sebelah utara untuk mencapai pusat Kota payakumbuh. Terutama sekali bagi 
pendatang dari kecamatan Harau Kabupaten Lima Puluh Kota dan pendatang dari Provinsi Riau.

Letak astronomis kawasan bagian utara Kota Payakumbuh adalah $0^{\circ} 8^{\prime}-0^{\circ} 15^{\prime}$ LS dan $100^{\circ} 20^{\prime}-100^{\circ} 40^{\prime} \mathrm{BT} \quad 100^{0} 20^{1} \quad-100^{0} 40^{\mathrm{l}} \mathrm{BT}$ dengan ketinggian antara 514 dampai 517 diatas permukaan laut, suhu udara rata-rata $26^{\circ}$ sampai $27^{\circ} \mathrm{C}$ dan kelembapan $45 \%$ - 50\% dengan luas daerah 1.452,8 $\mathrm{Km}^{2}$. Kawasan bagian utara Kota Payakumbuh memiliki 25 kelurahan dan dilewati 4 aliran sungai.

Berdasarkanbatasadministrasi,Kecama tanPayakumbuhUtaramempunyaibatasbatassebagaiberikutSebelah Utara berbatasandenganKec Harau dan $\mathrm{Kec}$ Payakumbuh Kabupaten Lima Puluh Kota, Sebelah Selatan berbatasandenganKecamatan Payakumbuh Barat,

SebelahTimurberbatasandenganKecamatan

Payakumbuh Timur, Sebelah Barat berbatasandenganKecamatanLamposi Tigo Nagori.

Jumlah kelurahan di Kecamatan Payakumbuh Utara berjumlah 25 (Dua Puluh Lima) kelurahan, 49 RW (Rukun Warga) dan 123 RT (Rukun Tetangga). Kecamatan Payakumbuh Utara dilalui oleh 4 sungai dengan lebar $5 \mathrm{~m}$ hingga $20 \mathrm{~m}$ diantaranya Sungai Batang Agam, Batang Lampasi, Batang Sinama dan Batang Pulau.

Penduduk Payakumbuh Utara tahun 2016 berjumlah 30.679 jiwa yang terdiri dari 15.241 jiwa penduduk laki-laki dan 15.438 jiwa penduduk perempuan dengan sex ratio $98,72 \%$.

Material padat pembentuk permukaan Kota Payakumbuh terdiri daripenyebaran material tersebut merupakan hasil dari berbagai proses yang berasal dari dalam bumi (endogen) dan dari luar (exogen).

Geomorfologi (pola bentang alam) Kota Payakumbuh, hampir monoton, yaitu sebagai dataran (92,30\%). Hanya 7,70\% sebagai perbukitan dengan elevasi maksimum $+825 \mathrm{~m}$ dpl. Seluruh perbukitan terletak di batas barat daya dan selatan Kota Payakumbuh, dan tidak/belum signifikan untuk perkembangan Payakumbuh sebagai suatu kota ciri geomorfologi paling menonjol adalah jaringan alur sungai yang secara umum mengalir dari barat daya ke timur laut dan bergabung ke Batang Sinamar.

Secaratopografiswilayahstudidapatdike lompokkanatasenamkelaskemiringanlahan, yaitudatar $(0-2 \%)$, agaklandai $(3-8 \%)$, landai $(8-15 \%)$, agakcuram $(15-30 \%)$, curam $(30-45 \%)$ dansangatcuram (> 45\%).Secaraumum Kota Payakumbuhberdasarkankondisitopografiny adengantingkatkemiringan (0-8\%) Datar dan $(8 \%$ - 14\%) Landai.

KecamatanPayakumbuh Utara tidakseluruhnyaterkonsentrasipadapertanian, sebagiandariwilayahKecamatanPayakumbuh Utara jugaberadapadadaerahpusatkota yang merupakandaerahpemukimanpenduduk yang padatdanpusatbisnissertajasa di Kota Payakumbuh.

PadawilayahTimurKecamatanPayaku mbuh Utara mengalirsungai yang cukuplebardengannamaBatangAgamdanpad awilayah Barat dan Utara mengalirsungaidanirigasiantara lain BatangLampasi, Batang Pulau dan Batang Sinamar.

Keempatsungaitersebutsangatbermanfaatunt ukirigasisawahdankolamikanpenduduk.

Tabel1.Perubahan pengunaan lahan 


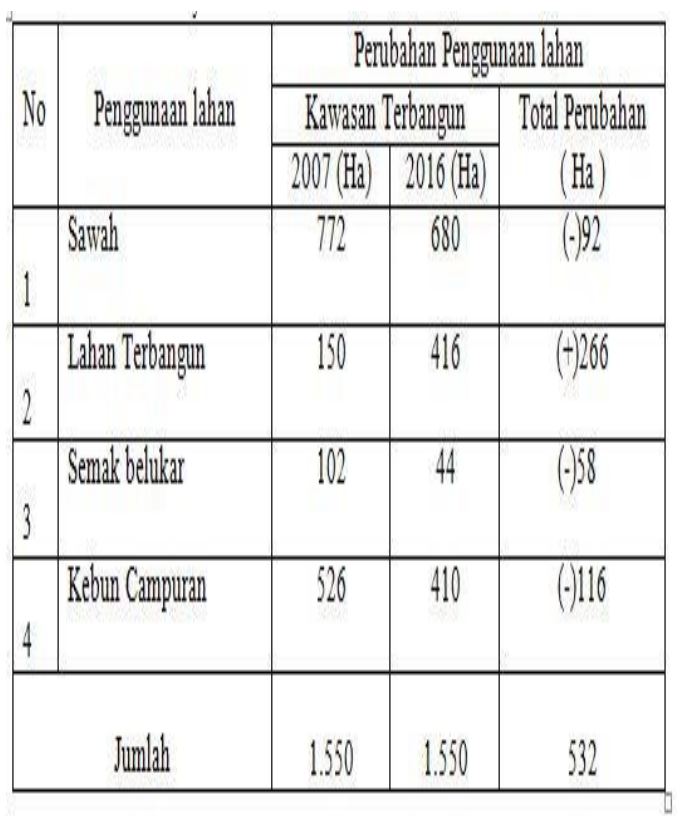

Sumber :Analisis data penelitian

Dari Tabel diatas Dapat dilihat bahwa total perubahan penggunaan lahan untuk kawasan terbangun bagian utara Kota Payakumbuh tahun 2007dan2016 yaitu 532 Ha. Perubahan penggunaan lahan untuk kawasan terbangun ini fluktuatif, artinya terdapat kenaikan dan penurunan jumlah luas perubahan.

Berikutketerangandari tabel diatas yang terdapat4 (empat) klasifikasiyaitu :

\section{Lahan terbangun}

Perubahanpenggunaanlahan yang terjadipadaKecamatanPayakumbuh Utarameliputisemuakelurahan di kecamatanini, tetapi yang paling dominanyaitulahanterbangunpadaKelurahan Napar, Labuh Baruyaitupada tahun 2007sebesar150Ha.

Setelahadanyapeningkatan jumlah penduduk dan pembangunan yang cukup pesat pada 10 tahun terakhir Kecamatan Payakumbuh Utara naikmencapai416Ha padatahun 2016.Perubahanpenggunaanlahanakibatpere ncanaanpembangunan yang cukup pesatKecamatan Payakumbuh Utara sangatdidominasiolehlahanterbangun.

Gambar 2 merupakan Perubahan Penggunaan Lahan pada Lahan terbangun yang terjadi di Kelurahan Padang Kaduduk

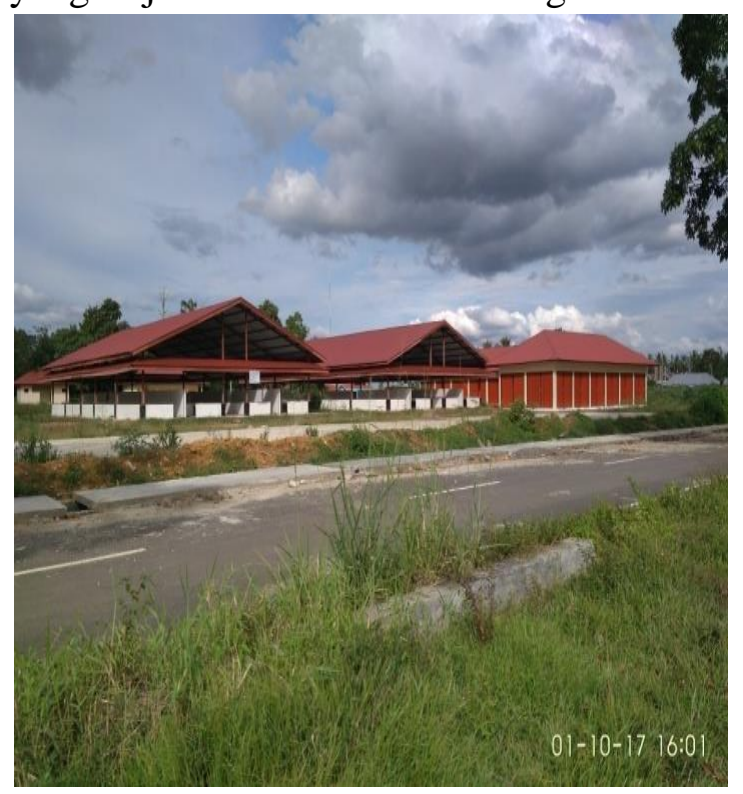

Gambar 2. Perubahan Penggunaan Lahan

Pada Lahan Terbangun

1. Sawah

SeiringperkembanganpembangunanKeca matanPayakumbuh Utaraareal pertaniansepertisawahsangatbergantungpada pasokan air sepanjangjaringanirigasimasihmengaliri air makalahanpertaniantetapberjalanpadatahun 2007sebanyak772 Ha namunberkurangpadatahun 2016menjadi680Ha, Hal inidikarenakanbanyaknya areal sawah, Kebun Campuran dan Semak Belukar menjadi areal lahanterbangun.

Gambar 3 merupakan Perubahan Penggunaan Lahan yang terjadi yang sebelumnya sawah berubaha menjadi Lahan Permukiman di Kelurahan Payonibuang 


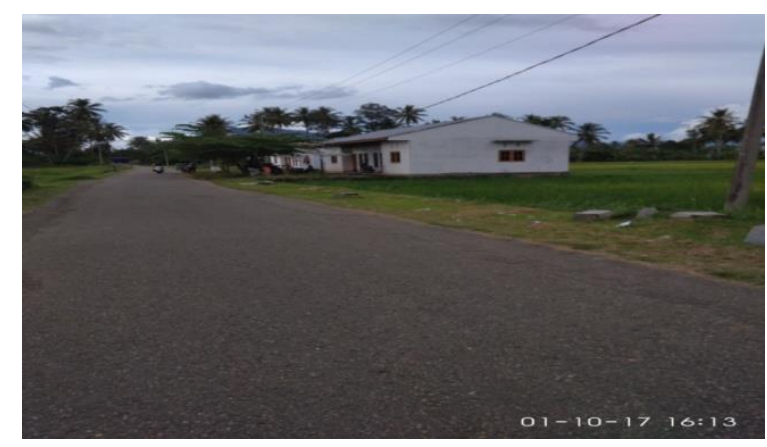

Gambar 3. Perubahan penggunaan lahan dari sawah menjadi lahan permukiman

2. Semak Belukar

Semakbelukarluasnyaberkurangselama 10 (sepuluh) tahunterakhirini yang dimulaidaritahun 2007sebanyak $102 \mathrm{Ha}$, danpadatahun 2016 sebanyak44Ha. Berkurangnya

semakbelukarinidisebabkanalihfungsisemak belukarmenjadikebuncampuran, lahanterbukadansawah.Semakbelukarinibany akdijadikanmasyarakatmenjadikebuncampur andanpenambahan area lahan permukiman, halinilah yang menyebabkansemakbelukardaritahunketahun nyaberkurang.

Gambar 4 merupakan perubahan penggunaan lahan yang awalnya semak belukar menjadi perumahan yang terjadi di Kelurahan Napar

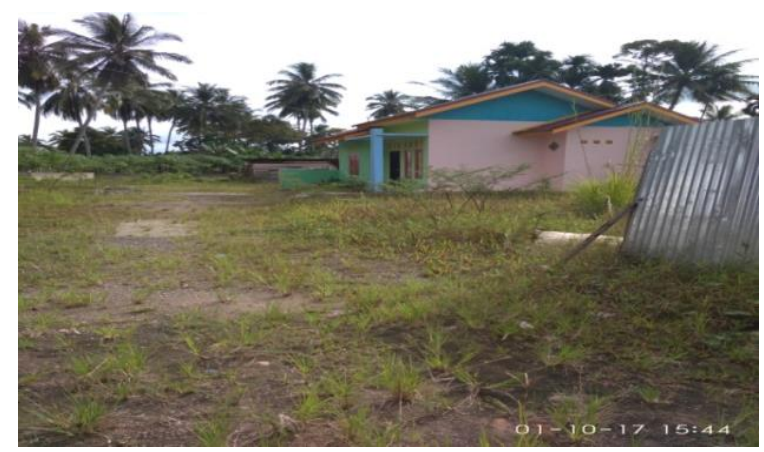

3. Kebun Campuran

Luaskebuncampuranberkurangdalam 10 (sepuluh) tahunterakhirberikuthasilinterpretasicitrapad atahun 2007 sebanyak526Ha sedangkantahun 2016sebanyak 410Ha. Hal inidikarenakanbanyaknya areal kebuncampuran yang berada di KelurahanNapar,TarokdanPadang Kadudukberubahmenjadilahanterbangun.

Gambar 5 merupakan perubahan penggunaan lahan yang awalnya kebun campuran berubah menjadi Permukiman di Kelurahan Padang Kaduduk

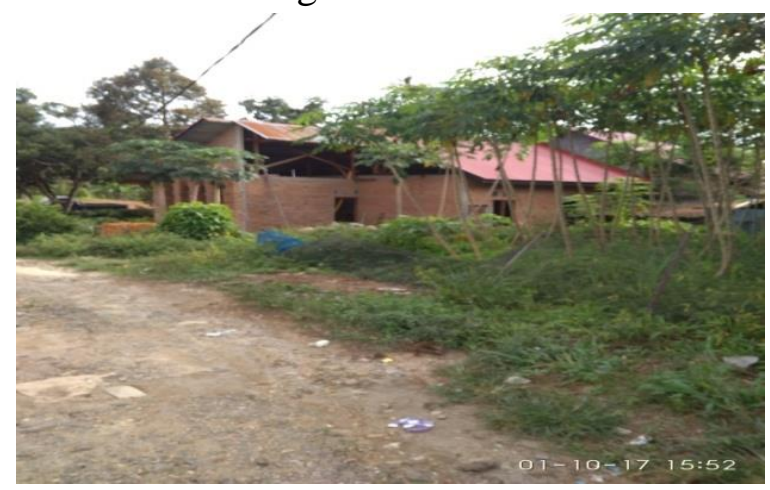

Gambar 5. Perubahan penggunaan lahan dari kebun campuran menjadi permukiman warga Berdasarkan perubahan yang terjadi akibat peningkatan pembangunan yang cukup pesat dan peningkatan jumlah penduduk maka banyaknya perubahan kebun campuran menjadi lahan terbangun, sawah menjadi lahan terbangun dan banyak yang lainya sehingga perkembangan ini tidak merumuskan bentuk namun hanya melihat proses atau tahap-tahap dari perubahan penggunaan lahan yang terjadi dengan lokasi penetapan berdasarkan lokasi sebaran sampel melalui survey lapangan pada tahun 2017.

Gambar 6 merupakan Peta Kawasan Terbangun pada tahun 2007yang terletak di Bagian Utara Kota Payakumbuh 


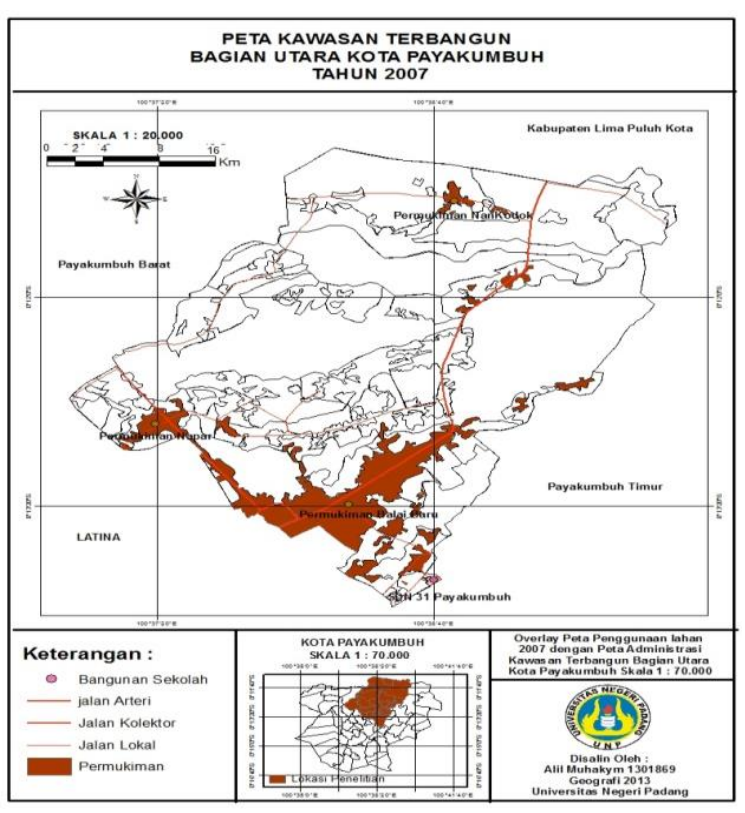

Gambar 6. Peta Kawasan terbangun bagian utara kota payakumbuh tahun 2007

Gambar 7 merupakan Peta Kawasan Terbangun pada tahun 2016 yang terletak di Bagian Utara Kota Payakumbuh

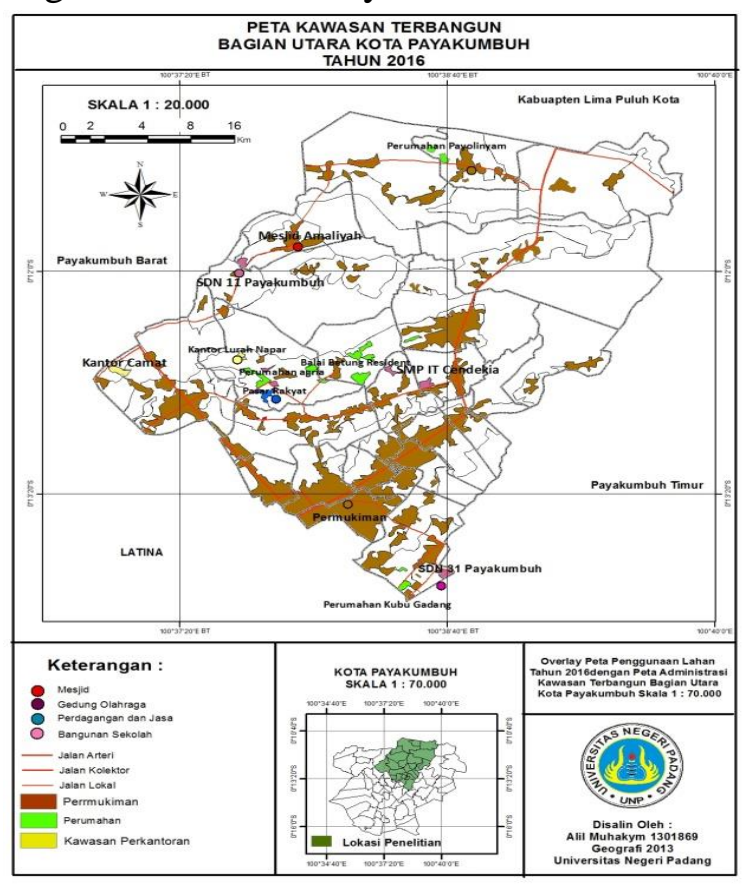

Gambar 7. Peta Kawasan terbangun bagian utara kota payakumbuh tahun 2016

Berdasarkanperubahan

yang terjadiakibat peningkatan pembangunan yang cukup pesat dan peningkatan jumlah penduduk

makabanyaknyaperubahankebuncampuranm enjadilahanterbangun,

sawahmenjadilahanterbangundanbanyak

yang

lainyasehinggaperkembanganinitidakmerum uskanbentuknamunhanyamelihat proses atautahap-

tahapdariperubahanpenggunaanlahan yang terjadidenganlokasipenetapanberdasarkanlok asisebaransampelmelalui survey lapanganpadatahun 2017.

Tabel 2.Perubahan pengunaan lahan

\begin{tabular}{|c|c|c|c|c|c|}
\hline$N_{0}$ & Klasifikasi & $\begin{array}{l}\text { Tahun } \\
2007(\mathrm{Ha})\end{array}$ & $\begin{array}{l}\text { Tahun } \\
2016\left(\mathrm{H}_{2}\right)\end{array}$ & $\begin{array}{c}\text { Perubaha } \\
\text { nluas } \\
2007- \\
2016\end{array}$ & \begin{tabular}{l|l} 
Keteranga \\
il
\end{tabular} \\
\hline 1 & $\begin{array}{l}\text { Lahan } \\
\text { Terbangun }\end{array}$ & 150 & 416 & 266 & $(+)$ \\
\hline 2 & Sawah & 772 & 680 & 92 & $(6)$ \\
\hline 3 & Senk betukat & 102 & 4 & 58 & $(6)$ \\
\hline 4 & $\begin{array}{l}\text { Kebua } \\
\text { Campuran }\end{array}$ & 526 & 410 & 116 & ( \\
\hline & Jumlah & 1550 & 1.550 & 532 & \\
\hline
\end{tabular}

Dari tabel diatas dapat dilihat bahwa perubahanluas penggunaan untuk kawasan terbangun bagian utara Kota Payakumbuh selalu mengalami peningkatan dari tahun 2007. Hal ini dapat dilihat bahwa luas lahan terbangun bagian utara Kota Payakumbuh pada tahun 2007 yaitu 150 ha meningkatan menjadi 410 ha pada tahun 2016, berarti terjadi penambahan luas lahan terbangun sebesar 266 ha selama 10 tahun terakhir.

Berdasarkan hasil analisis dapat diketahui bahwa pada tahun 2007 luas sawah yang dijadikan sebagai kawasan terbangun yaitu 772 ha dan pada tahun2016 menurun menjadi 680 ha, artinya terjadi penurunan 
sebesar 92 ha. Kondisi sebaliknya terjadi pada lahan terbangun dimana pada tahun 2007 luas lahan terbangun yaitu seluas 150 ha dan pada tahun 2016 terjadi peningkatan menjadi 416 ha, berarti terdapat penambahan luas penggunaan lahan terbangun sebesar 266 ha.

Sedangkan pada lahan kebun campuran dimana pada tahun 2007 luas lahan kebun campuran yang dijadikan sebagai lahan terbangun yaitu seluas 526 ha dan pada tahun 2016 lahan berkurang menjadi 410 ha Hal ini disebabkan karena lahan kebun campuran ini mengalami perubahan penggunaan lahan menjadi lahan terbangun. Kondisi ini sesuai dengan analisis data yang menunjukkan bahwa adanya lahan kebun campuran yang dijadikan sebagai lahan terbangun seluas 76 ha.

Sedangkan untuk lahan semak dan belukar yang dijadikan sebagai lahan terbangun menunjukkan sedikit perubahan. Untuk lahan semak belukar pada tahun 2007 sebesar 102 ha. Sedangkan pada tahun 2016 lahan semak belukar sedikit berkurang sebesar 44 ha, artinya terdapat penurunan sekitar 58 ha karena lahan semak belukar dijadikan sebagai lahan terbangun.

Dengan demikian dapat disimpulkan bahwa perubahan penggunaan lahan untuk kawasan terbangun bagian utara Kota Payakumbuh tahun 2007 dan 2016 selalu meningkat dari tahun ke tahun, kondisi ini disebabkan karena adanya perubahan penggunaan lahan dari lahan sawah, kebun campuran, dan semak belukar menjadi lahan terbangun sehingga lahan terbangun pada tahun 2007 yang terdapat pada lahan sawah, kebun campuran dan semak belukar berubah letaknya pada lahan terbangun karena adanya perubahan fungsi lahan

Gambar 8 merupakan Peta Penggunaan Lahan pada tahun 2007 yang terletak di Bagian Utara Kota Payakumbh

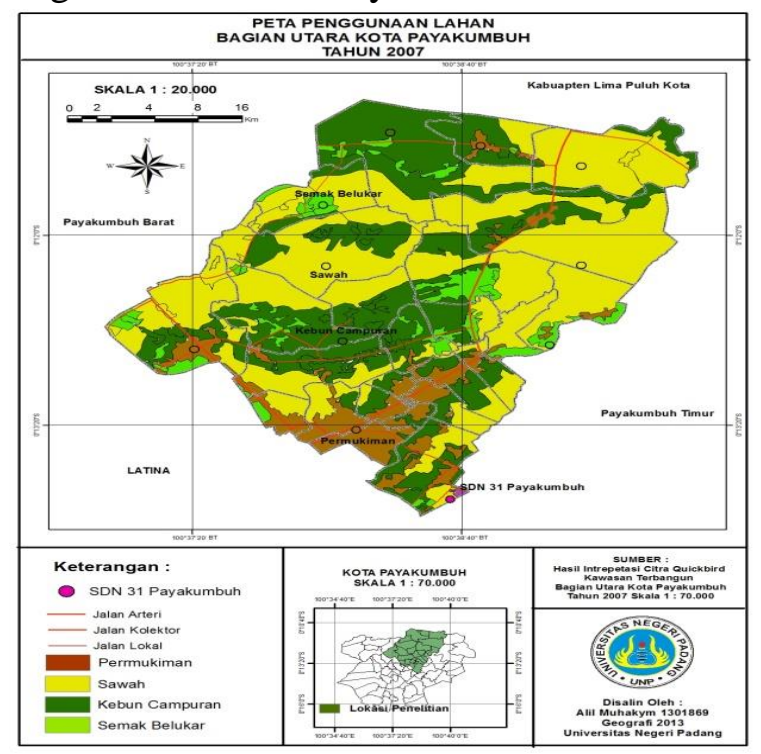

Gambar 8. Peta Penggunaan lahan bagian utara kota payakumbuh tahun 2007

Gambar 9 merupakan Peta Penggunaan Lahan Pada tahun 2016 yang terletak di Bagian Utara Kota Payakumbuh

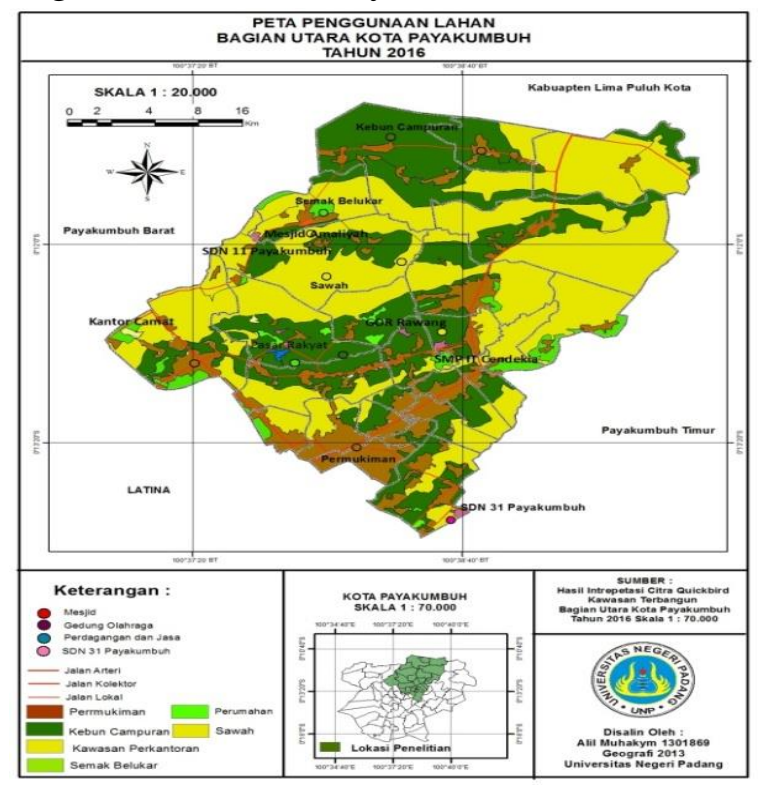

Gambar 9. Peta Penggunaan lahan bagian utara kota payakumbuh 2016 


Klasifikasipenggunaanlahan yang
perubahan yang
meningkatyaitulahanterbuka, lahanterbangun
yang sebelumnyasawah,
kebuncampuran,semakbelukar.Areal yang
paling banyakberkurangperubahannyayaitu
areal kebun campuran.Dari hasil survey yang
ditemukandilapanganperubahan
penggunaanlahansawahditemukanadanyaper
ubahan yang
cukuptinggimenjadilahanterbangundikarena kantingginyapertumbuhanpendudukdantingg inyapermintaanuntuk areal lahanterbangunmeningkat.

Dilihatpadapetapenggunaanlahantahun 2007dan 2016dapatditarikkesimpulan, terjadinyapenambahanluaslahanterbangunse dangkanuntuk sawah, semak dan belukardanluasKebun

campuranberkurang.Selain adanya peningkatan luas lahan terbangun juga terdapat adanya perubahan penggunaan lahan untuk pemukiman di kawasan bagian utara Kota Payakumbuh.

Menurut hasil analisis data diketahui bahwa total perubahan penggunaan untuk kawasan terbangun bagian utara Kota Payakumbuh pada tahun 2007 dan 2016 yaitu 532 ha. Perubahan penggunaan lahan untuk kawasan terbangun bagian utara Kota Payakumbuh ini selalu meningkat dari tahun ke tahun yaitu terdapat kenaikan dan penurun jumlah luas perubahan. Perubahan penggunaan lahan yang terjadi yaitu dari sawah, kebun rakyat dan semak belukar menjadi lahan terbangun. Sedangkan lahan sawah dan kebun campuran merupakan lahan perubahan dari kebun rakyat, dimana pada tahun 2016 lahan ini juga dijadikan sebagai lahan terbangun.
Perubahan luas lahan terbangun bagian utara Kota Payakumbuh selama kurun waktu 10 tahun terjadi peningkatan sebesar 266 ha dimana pada tahun 2007 yaitu sebesar 150 meningkat menjadi 416 pada tahun 2016. Peningkatan luas lahan terbangun bagian utara Kota Payakumbuh disebabkan karena beberapa faktor yaitu peningkatan jumlah penduduk setiap tahunnya.

Dari perubahan penggunaan lahan pada saat ini yang dikaitkan dengan Rencana Pembangunan Jangka Panjang Daerah (RPJPD) Tahun 2005-2025 di mana visi pembangunan jangka panjang Kota Pyakumbuh untuk tahun 2025 adalah terwujudnya Kota Payakumbuh sebagai kota maju dengan pengembangan usaha mikro, kecil dan menengah.

RPJMD pada Peraturan Daerah Kota Payakumbuh Nomor Tahun 2013 tentang Rencana Pembangunan Jangka Menengah Daerah (RPJMD) Tahun 2012 - 2017 bahwa potensi lahan yang tersedia untuk pembangunan pada kawasan terbangun bagian utara Kota Payakumbuh pada masa mendatang cukup besar.

RPJMD yang mengarah ke Bagian Utara Kota Payakumbuh tergantung visi dan misi walikota dan wakil walikota terpilih dimana misi walikota terpilih tersebut adalah menjadikan Kota Payakumbuh sebagai pusat pertumbuhan ekonomi baru berbasis ekonomi kerakyatan di Sumatera Barat.

Struktur tata ruang kota yang berada pada daerah kawasan bagian utara Kota payakumbuh yaitu Sub Pusat Pelayanan Utara dengan pusat terletak di Payolinyam Nan Kodok. Sub Pusat ini dikembangkan dengan membangun psar satelit untuk pelayanan pasar sekitarnya yang ditunjang 
oleh pembangunan serta kawasan perdagangan yang berbentuk toko atau ruko.

Kawasan strategis perdagangan dan jasa akan dikembangkan sepanjang jalan poroskawasan utara Payakumbuh menuju Pekanbaru yang terletak dikelurahan Payolinyam dan Nan Kodok sebagai pusat oleh2 khas Payakumbuh. Strategi pembangunan ini mencakup upaya pemanfaatan nilai strategis yang dimiliki Kota Payakumbuh melalui pengembangan infrastruktur terkait sehingga kegiatan perdagangan antar kota dapat ditingkatkan secara lebih cepat.

Pola permukiman di kawasan ini dengan pembagian rencana tata ruang menurut SUB BWK dengan BWK di Kota Payakumbuh adalah adalah permukiman padat seperti di Kelurahan Labuh Baru, Napar, Bunian,, Tarok dak Koto Baru. Dari aspek tata ruang kawasan permukiman padat ini perlu penataan kembali.

\section{PENUTUP}

\section{Kesimpulan}

Klasifikasiperubahanpenggunaanlahan di bagian utara Kota Payakumbuhterdapat empatklasifikasidiantaranyayaitukebuncamp uran, sawah, lahanterbangun,semakbelukar.Keempatklasif ikasiinisudahmewakilipenggunaanlahan

yang terjadisetiaptahunnya. Perubahanpenggunaanlahan di bagian utara Kota Payakumbuhdaritahun 2007sampaitahun

2016terusmengalamipeningkatanpadabebera paklasifikasipenggunaanlahan, dimanaperubahanpenggunaanlahan yang paling dominanterjadipadalahanterbangunyaitu 150 Ha.
Sedangkanuntukbeberapaklasifikasitutupanl ahansepertisemakbelukar, kebuncampuran, sawahmengalamipenurunan.

Perubahan luas lahan terbangun bagian utara Kota Payakumbuh selama kurun waktu 10 tahun terakhir terjadi peningkatan sebesar 150 ha di mana pada tahun 2007 sebesar 1.550 ha meningkat menjadi 1.550 ha pada tahun 2016, ini disebabkan karena beberapa faktor yaitu meningkatnya pertumbuhan penduduk dari tahun ke tahunnya.

\section{Saran}

Perubahanpenggunaanlahaniniperlumend apatkanpengawasandaripemerintahdaninstan si yang terkait agar terciptanyalingkungan yang

selarasdanmelakukanpengarahanpembangun an agar tidakmengganggufungsikawasan yang

adadanmerusaklingkungandanekosistem yang ada.

Sebelummelakukankebijakandalammanaj emenlahandengan saran yang telahdikemukakan, perludilakukananalisisfungsikawasandanmer ujukpadaketetapanproduksifungsilain, disesuaikandenganundangundangrencanatataruangwilayah (RTRW).

\section{DAFTAR PUSTAKA}

BPS. 2008. Kota Payakumbuh Dalam Angka Tahun 2008. Payakumbuh. BPS Kota payakumbuh

BPS. 2017. Kota Payakumbuh Dalam Angka Tahun 2017. Payakumbuh. BPS Kota payakumbuh

Haryadi, 2007.Perhitunganerosikuantitatifmet ode MMF dengan PJ dan SIG di DAS 
BenainNoelmina.JurnalIlmu Tanah

danLingkungan. 7(2): 127- 132.

Indarto. 2014. Teori Praktek Pengindraan Jauh. Andi Offset: Jakarta.

Lillesand Kiefer. 1994. Pengindraan Jauh dan Interpretasi Citra. Gadjah Mada University Press. Yogyakarta.

Muta'ali, Lutfi. 2012.

DayaDukungLingkunganUntukPeren canaanPengembangan

Wilayah.BPFG UGM.Yogyakarta.

Nawi, Marnis dan Khairani. 2009. MetodologiPenelitianGeografi.

Padang : UNP Press.

Rustiadi, E. danWafda, R. 2007.Permasalahanlahanterlantardan upayapenanggulangannya.Seminar PertanahandanDeklarasiBarisan Indonesia Kabupaten

Bogor.InstitutPertanian Bogor. Bogor. 224 p. 